\title{
Water Resources Development in Thailand
}

\author{
Siriprapha Jitanugoon ${ }^{1}$, Pittinun Puntha ${ }^{1 *}$, and Po-Chih Lee ${ }^{2}$ \\ ${ }^{1}$ Department of Business Administration, National Yunlin University of Science and Technology, Taiwan \\ ${ }^{2}$ Department of Asia-Pacific Industrial and Business Management, National University of Kaohsiung, Taiwan \\ *Corresponding author
}

\begin{abstract}
.
It is estimated that more than half the world's wetlands have disappeared. Agriculture consumes more water than any other source and wastes much of that through inefficiencies. Climate change is altering patterns of weather around the world, causing water shortages and droughts in some areas and floods in others. Water is a renewable resource that is necessary to life. Uses of water include agricultural, industrial, service, household, recreational and environmental activities. All living things require water to grow and reproduce. The government of Thailand now intends to promote a knowledgebased economy for increasing GDP per capita to a high level. Due to climate change, unbalance water uses in the economy, and political factor, Thailand is currently facing its worst drought problems in 40 years. The government of Thailand needs to develop strategies to properly manage water resources in order to ensure freshwater supply for domestic usage in all areas. Water management strategic plans have been emphasized in water demand, supply, reservoir management, reduction of water loss, and finding new freshwater sources.
\end{abstract}

Keywords: Climate, Desalination, Fresh Water, Mekong River, Water Management

\section{Introduction}

Thailand is the 50th-largest country in the world by land area and the 22nd-most populous. It is composed of 76 provinces covering 513,120 square kilometers, with a population of over 66 million people (Macrotrends, 2021). Thailand is bordered to the north by Myanmar and Laos, to the east by Laos and Cambodia, and to the south by the Gulf of Thailand and Malaysia (Central Intelligence Agency). Thailand is classified as a newly industrialized country, with a 2019 GDP of US\$1.39 trillion based on purchasing power parity (Prachimdhit, 1990). It is the second largest economy in Southeast Asia after Indonesia and is the 4th richest nation according to GDP per capita after Singapore, Brunei, and Malaysia (Brown, 2013). Thailand functions as an anchor economy for the neighboring developing economies of Laos, Myanmar, and Cambodia

\section{Climate}

Thailand's weather is divided into three seasons. The first is the raining or southwest monsoon season from mid-May to mid-October, which is caused by southwestern wind from India ocean. Winter or the northeast monsoon occurs from mid-October until mid-February. Most of Thailand experiences dry weather with mild temperature. Summer or the pre-monsoon 
season runs from mid-February until mid-May. Due to its inland nature and latitude, the north, northeast, central and eastern parts of Thailand experience a long period of warm weather (Thai Meteorological Department, 2021).

\section{Water situation}

Currently, Thailand consumes more than 90 percent of its fresh water for agricultural production, which is much higher than that of developed nations ranging from 41 percent to 68 percent (Ngammuangtueng et al, 2019). Forty-nine percent of Thailand's labor force is employed in agricultural sector (Udomkerdmongkol and Chalermpao, 2020). Rice is the most important crop in the country and Thailand had been the world's largest exporter of rice, until recently falling behind both India and Vietnam (Suebpongsang, 2020). Thailand has the highest percentage of arable land with 27.25, compared with any nations in the Greater Mekong Subregion. About 55 percent of the arable land is used for rice production, and most of them using irrigation (Market Research Southeast Asia, 2021).

\section{Strategies}

\subsection{Water demand management}

Water demand is defined as the amount of water required for the following three main purposes: irrigation, domestic, and industrial and also in tourism. Water storage refers to the "design capacity" which is greater than the amount of water that will be available for use. A growing population directly affects the amount of additional water required by personal and domestic use. In addition, population growth has expanded economic activities, such as agriculture and industry, which also require additional water. It is important to understand the structure of the water supply or the organization that serves the water user and operated in order to provide services according to user demand and to create incentives for efficiency.

In mid-2007, the Thai government announced "water" as one of the important national agendas to celebrate the 80th birthday of the 9 Kings. The focus of this policy is to increase public awareness and cooperation on water resources management. In particular, the proposed classification of water use, and the proposed water tariff have caused a lot of debate among all parties. Commercial and very large water users will be required to register and pay fees.

In particular, Thailand's master plan focuses on raising GDP per capita in the country and develop agriculture by focusing on research and development that uses new technology to produce product quality and processing meet international requirements. Besides, these strategies continue to improve the management of natural resources and the environment that are the basis of agricultural production. For example, smart farming projects which help farmers can grow plants that are suitable with each topography and able to withstand inclement weather. Furthermore, The Office of the Natural Resource and Environmental Policy and Planning issued the National Water Resources Management Strategies (2015-2026) which involved in water demand management is given to the following strategies:

- Managing water for consumption; This strategy's objective is to provide consumable water for every village, urban community, economic zone and important tourist attractions nationwide. The goals are to develop village-water-supply in 7,490 villages, recondition village-water-supply in 9,093 villages, increase the waterworks system in 225 urban communities and expand the waterworks system into 688 areas. 
- Provides water security in the production sector, agricultural sector and industrial sector. The goal is to develop no less than 9.5 billion cubic meters of restored water sources and increase no less than 1.3 million hectares ( 8.7 million Rai) of irrigation water sources, provide 2,700 million cubic meters water sources of rain-fed agricultural areas, excavate 270,000 ponds in the paddy fields and develop ground water supply for agriculture for 166,400 hectares $(10.4$ million Rai).

\subsection{Water Supply}

Over the past 40 years, Thailand has faced a shortage of water which comprises of many droughts, it has a huge impact on farmers' income and the country's economic output. Severe droughts that occurred in 1979, 1994 and 1999. It has affected almost every part of the country and has seen a number of repeated droughts in the past 10 years, which have affected a total area of around $42,280 \mathrm{~km}^{2}$. As for the household water shortage problem, it was found in 2017 , approximately 75,000 villages in Thailand do not have a centrally controlled water supply system (ONEP, 2020).

In addition to droughts, over the past 30 years Thailand has experienced flooding in almost all provinces of the country, causing damage to life, property and the economy. In 2011, Thailand faced major flooding, which impacted over 13 million people, with resultant economic damage costing more than 0.46 trillion USD (ONEP, 2020).

Therefore, in order to effectively manage the country's water resources, Thailand has formulated the National Water Resources Management Strategies (2015-2026) and the 20-Year Master Plan on Water Resources Management (2018-2037), both of which are in line with the plan of the 20-Year National Strategy (2018-2037) (ONEP, 2020).

Master Plan for Thailand Water Resources Management. (2018-2037) has set the vision for development as follows "Every village has clean water for consumption, ssustainable water production, the damage from flooding is reduced, and the water quality is up to the standard, sustainable water management under balanced development with the participation of all sectors" (ONWR, 2018, A).

About reservoirs management in Thailand for drought problem, Thai government has measures and action plans to cope with drought conditions in drought-prone areas. For shortterm plan such as increase water reservoirs, drilling artesian well, support car to distribute water, royal rain operation, campaign to reduce farmland. For long-term plan such as promote additional water sources reserve for farmers, campaign to grow water-based economic crops little, increase the efficiency of the irrigation system, and water laws regulate water management in crisis drought conditions. It also has "Emergency Continuous Management Plan", this plan prepared to the officer responsible for the reservoir can be used in management and operations in critical conditions or emergency situations that happened to the reservoir. Whether caused by natural disasters such as floods, earthquakes, accidents or terrorism (Royal Irrigation Department, 2020).

\subsection{Mekong River water management}

China has the largest hydroelectric power in the world with a total installed capacity of 356 GW in 2019, which is larger than the United States' 103 MW, Canada's 81 GW, and Japan's $50 \mathrm{GW}$ combined. Nevertheless, the Chinese Government recently announced that it intends to build additional $60 \mathrm{GW}$ hydroelectric power projects on Prahmaputra River, known as the 
Yarlung Tsangbo River in Tibet during the period 2021-2025. The buildings of these hydroelectric power projects could spark downstream serious impacts on water supply, irrigation, and biodiversity in India, Bangladesh, Thailand, Cambodia, and Vietnam (ONWR, 2021, D).

From the extraordinary general meeting of the Thai Mekong Committee No. 2/2020 on August 3, 2020, at the Government House of Thailand. It was concluded as follows; approved the draft Mekong River Basin Strategy 2021-2025 and draft an MRC Strategic Plan 2021-2025. In the details are as follows 1 . The Mekong river basin strategic plan will establish directions and guidelines for the management of water and related resources. Including guidelines for the management and conservation of the Mekong river basin during next 10 years. 2. Has been linked The Mekong-Lan Xang Cooperation Framework to cover all six countries (China, Myanmar, Thailand, Lao PDR, Cambodia and Viet Nam) in the Mekong Basin Systematically. 3. Continued funding with Development Partners for support driving operations according to the next plan (ONWR, 2021, C).

About Mekong River Commission (MRC) they have "The MRC Strategic Plan (SP) 20212025 ", this plan is an all-in-one organizational plan that integrates with Integrated Water Resources Management (IWRM)-based Basin Development Strategy (BDS) 2021-2030. The SP sets out how the MRC will contribute to the implementation of the BDS 2021-2030 and strengthen the organization for the next five years. It guides the actions of the MRC Secretariat in support member countries in promoting and coordinating sustainable development of the Mekong River Basin. The strategy covers all water and related sectors and is integrated in the Sustainable Development Goals (SDGs) related to the management of water resources and internalization a 'gender and vulnerability' guidelines for determining inequality, intersections and dimensions of vulnerabilities (MRC, 2021, A). Moreover, BDS 2021-2030 expand sustainable development opportunities with environmental and social investment opportunities including Hydropower development, Irrigated and climate-smart agriculture development, development of navigation, leveraging the value, flood and drought mitigation, sustainable livelihoods, and fisheries and aquatic resources. These approach encourages the establishment of joint venture programs between two or more nations, as well as major national projects that produce domestic advantages and additional possibilities in the basin (MRC, 2021, B).

\subsection{Recycle fresh water}

Freshwater is a finite and vulnerable resource, essential to sustain life, development and the environment (Global Water Partnership, GWP). Reusing water in industry has the potential to reduce the costs of water supply and wastewater treatment by industries and reduces pressure on water resources. Owing to the increase of industrial activities has led to over-exploitation of water and the discharge of a large amount of water pollution load. The reduction of water consumption and the reuse of reclaimed water should arouse the attention of various industries.

Most industrial activities in Thailand are concentrated in the center of Thailand. Rivers in densely populated areas, such as the lower reaches of the Chao Phraya River, are easily polluted due to wastewater discharge from various factories. However, in the past few years, the wastewater treatment industry has been underdeveloped. Currently, only about $15 \%$ of the total water consumption is treated wastewater.

The Thai government has recognized this problem in its $12^{\text {th }}$ National Economic and Social Development Plan (2017-2021) and is currently cracking down on industrial wastewater. 
Currently, the problem is being solved at an accelerated pace by development and improvement of wastewater treatment efficiency and the management of wastewater treatment systems through the reuse of treated wastewater. The goals are to develop a wastewater treatment system in 201 communities and increase the efficiency of wastewater treatment systems in 47 communities. In addition, the Thai government has allocated substantial funds to local governments for the construction, renovation and monitoring of sewage treatment plants.

Furthermore, Industrial Estate also adjusted measures to effectively utilize natural resources through the use of "3Rs" (Reduce Reuse and Recycle) water management in accordance with the Circular Economy System. Consists of use of solar energy in the production of water supply and wastewater treatment (Jang, 2020). Building a water management learning center for sharing knowledge, established the Smart System, building stations for wastewater treatment and wastewater recycling and creating understanding of effective water management by thinking of the impact in every dimension such as economic, social and environment. As a result, all recycling wastewater systems in industrial estates can save or reduce the use of water up to $15-40 \%$. Therefore, the efficiency of water management through the $3 R$ s and the wastewater recycling process will directly affect the total water usage, reducing competition in the use of water with the community in the future especially in the period of the drought crisis (Wichai-utcha and Chavalparit, 2019).

\subsection{Find new fresh water sources}

Fresh water is a necessity for human beings and is essential for maintaining healthy ecology and socioeconomic conditions and pressure. At present, Thailand consumes $90.4 \%$ of fresh water for agricultural activities, while upper-middle-income countries and high-income countries consume only 67.8 and $40.8 \%$, respectively (Opendevelopmentmekong., 2017). One of the main factors leading to this change is the development of irrigation schemes, which are vital to the development of domestic and export agriculture in Thailand to provide livelihood opportunities for Thai citizens. However, rainfall storage in Thailand averages only $30 \%$ of total rainfall volume, with shortages of ten occurring at the time when agricultural demand is highest. This has become a critical issue that worsened over time.

Therefore, Thai government and The Agriculture and Cooperatives Ministry is planning to expand water storage capacity by building an additional 421 water storage facilities, building 541,000 small dams and restoring 3.5 million rai of watershed areas in the fight against a looming water shortage, which is believed to be the worst in 10 years. The new storage facilities will increase water capacity by 942 million cubic meters (Reliefweb., 2020). However, for the long run, if water stocks are still not enough or remain critically low, the government plan asks the Groundwater Resource Department to dig more artesian wells. Besides, Thai government has plans to build the pipelines to divert water from Cambodia's lakes to existing reservoirs and dams for transferring to water shortage areas in eastern part of Thailand.

\subsection{Desalination}

In response to the ongoing and future droughts plaguing the industrial sector, the Industrial Estate Authority of Thailand (IEAT) is planning to invest in a water desalination plant in the Eastern Economic Corridor (EEC). The water desalination plant will solve the water shortage in the long term and guarantee the eastern areas will not face future shortages.

IEAT will set up a subsidiary to launch a joint venture with a private company for this project. The aim is to ensure adequate supplies of water to facilities regardless of weather 
conditions. The plant, capable of desalinating 300,000 cubic meters of seawater per day, expanded from the previous plan for 30,000 cubic meters daily. It will supply water to factories in the area that has had to reduce water consumption in the past year due to extreme drought (Lamonphet, 2020).

In terms of agriculture, Thai government has the policy to construct a dam from Laem Chabang to the south. The aim is to release water to expel salt water to prevent it from affecting agricultural land and have more water storage for use in drought season. Moreover, the Department of Irrigation has developed the policy to close-open the floodgates which are connected to the Chao Phraya River following the rhythm of the sea water fluctuation and salinity.

\subsection{Water losses management}

Managing non-revenue water (NRW) in water distribution systems (WDS) is always a challenge for developing countries with a combination of poor infrastructures and poor operational practices. Particularly, Water loss due to the broken pipeline or leakage is still the main water management problem in Thailand. Due to leakages in the pipes throughout the distribution system more than 25 percent of the water is lost during transmission from the treatment plant to the households.

To reduce water loss, in the center of Thailand (Bangkok). The Metropolitan Waterworks Authority (MWA) is relying on ABB digital technology to keep track of where water is being used and where it's being lost by using more than $400 \mathrm{ABB}$ digital flow meters throughout Bangkok (ABB, 2020). The $\mathrm{ABB}$ flowmeter is one of the significant tools which provides high-resolution data that facilitates leakage detection and water network analysis in the Bangkok Metropolitan area. Thus, in densely populated urban environments, some of these meters are either buried underground or submerged in water (Islam and Babel, 2013).

To reduce water loss and benefit from the savings in other provinces, a district metering area (DMA) was applied as a management measure to control leaking water losses in each area. They created a surveillance system that was set up that compared the observed flow rates and the upper limit of warning values for each DMA. To further reduce these losses, sensitive warning values based on seasonal and daily patterns of water consumption were defined and implemented with an increased number of DMAs covering the entire service area (Jitong and Jothityangkoon, 2017).

Moreover, the government has set up a special command center chaired by the Prime Minister, to handle the crisis and assist affected villages. The center will oversee operations, situation forecasting, management, crisis warning and public relations. Besides, The Office of National Water Resources (ONWR) has been ordered to resolve the issue in the most effective and timely manner, requiring relevant agencies to cooperate to resolve pressing issues and formulate long-term water management plans. To make water management sustainable the government has established the new innovation, to help increase the efficiency of water management to be modern and sustainable by supporting the implementation of research results, information, inventions, innovations and various academic cooperation. Let's develop the country's water management to be up to date.

Correspond to climate change, environmentally friendly according to international standards and the way of life of the community. The government sees the importance of getting all information about water in one place and water management innovation in the form of Nearly 
Real Time Analytic. Provides convenient access to information and use and makes more accurate water management decisions. This innovation is called "One Map" which gives rise to the National Archives of Water and Climate Information. It is a compilation of a real-time database system from relevant agencies, including rain data, forecasts of rain and storms, water levels in various water resources. As well as the quality of water and disaster occurring under the same channel and also develop applications and research work to bring new knowledge mixed with the knowledge from the local villagers to manage water in different problems and needs (ONWR, 2018, B).

\section{Conclusion}

In general, Thailand has done well in the development of water resources. Though, still some issues in management specifically are caused by disunion of the management both in policy level and operational level. Therefore, Thai government aims to build the unity of the management by encouraging the establishment of organizations, laws, driven policies, supportive information systems for decision-making in planning, public relations plans to increase understanding of people and monitoring and evaluating implementation. Despite its difficulty, improving this issue is only the first step in water resource management cooperation among various parties. Moreover, demand-side management will become increasingly necessary, or even unavoidable, in the future due to the scarcity of resources. Consultation with the key stakeholders on the tradeoffs will be required throughout the planning and implementation of a water resource development project. Further, effective discussion on several options is possible only when they understand and are convinced that they will benefit from cooperation and will receive fair treatment.

\section{References}

ABB (2020). ABB technology helps ease Bangkok's water crisis. [Online]. Available:

Https://New.Abb.Com/. https://new.abb.com/news/detail/59086/abb-technology-helpsease-bangkoks-water-crisis

Brown, Justin. (2013). Southeast Asia: Region on the Rise. SCSC. [Online]. Available: https://www.scsc.vn/info_news_detail.aspx?ID=346.

Central Intelligence Agency. (n.d.). Thailand. Central intelligence agency. [Online]. Available: https://www.cia.gov/the-world-factbook/countries/thailand/\#transnationalissues.

Islam, M. S., \& Babel, M. S. (2013). Economic analysis of leakage in the Bangkok water distribution system. Journal of Water Resources Planning and Management, Vol. 139 No. 2, pp. 209-216.

Jang, T. (2020). หลก $3 R s$ ต้นแบบการจดการ “น้ำเสีย" ให้กลายเป็น “น้ำดี" ของ EEC. BLT

Bangkok. [Online]. Available: https://www.bltbangkok.com/news/25206/

Jitong, T., \& Jothityangkoon, C. (2017). Reducing water loss in a water supply system using a district metering area (DMA): A case study of the Provincial Waterworks Authority (PWA), Lop Buri Branch. Engineering and Applied Science Research, Vol. 44 No.3, pp. 154-160. 
Lamonphet A. (2020). New plant to address droughts. Bangkok Post. [Online]. Available: https://www.bangkokpost.com/business/1920360/new-plant-to-address-droughts

Macrotrends. (2021). Thailand Population 1950-2021. [Online]. Available: https://www.macrotrends.net/countries/THA/thailand/population'.

Market Research Southeast Asia. (2021). Capture the Prominence of Thailand Economies. Market Research Southeast Asia. [Online]. Available: https://www.marketresearchsoutheastasia.com/page/thailand

MRC ${ }^{a}$. (2021). Basin Development Strategy. MRC. [Online]. Available: https://www.mrcmekong.org/about/mrc/strategic-plans/

MRC $^{\mathrm{b}}$. (2021). The integrated water resources management-based Basin Development Strategy for the Lower Mekong Basin 2021-2030 and the MRC Strategic Plan 20212025. MRC. [Online]. Available: https://www.mrcmekong.org/assets/BDS-2021-2030and-MRC-SP-2021-2025.pdf

ONEP. (2020). Water Resources. Office of Natural Resources and Environmental Policy and Planning. [Online]. Available: https://climate.onep.go.th/wpcontent/uploads/2020/11/BUR_FINAL6-051120_PH.pdf

ONWR $^{\mathrm{a}}$. (2018). Master Plan for Thailand Water Resources Management. The Office of National Water Resources. [Online]. Available: http://www.onwr.go.th/en/?page_id=5286 ONWR $^{\mathrm{b}}$. (2018). Innovation and technology for the management of water resources in Thailand. The Office of National Water Resources. [Online]. Available: http://www.onwr.go.th/wpcontent/uploads/2019/11/การบริหารจดการทรพยากรน้ำ.pdf?fbclid=IwAR0vqz5H0bvd2U

\section{TISaPs5DPH 0Y6hbI4bDCrOrRzH6aUqaP71KsqpvJ6wsQ}

ONWR $^{\mathrm{c}}$. (2021). Thai National Mekong Committee Meeting No.2/2020. The Office of National Water Resources. [Online]. Available: http://tnmc-is.org/wpcontent/uploads/2020/09/TNMC\%20Meeting/TNMC\%202-2563.pdf

ONWR $^{\mathrm{d}}$. (2021). The Water Resources Management Strategies - Office of the National Water Resources. Office of the National Water Resources. [Online]. Available: http://www.onwr.go.th/en/?page_id=4207

Opendevelopmentmekong. (2017). Environment and natural resources. Open Development Thailand. [Online]. Available:

https://thailand.opendevelopmentmekong.net/topics/environment-and-natural-resources/

Ngammuangtueng, P., Jakrawatana, N., Nilsalab, P., \& Gheewala, S. H. (2019). Water, energy and food nexus in rice production in Thailand. Sustainability, Vol.11 No.20, 5852.

Prachimdhit S. (1990). Thailand and the So-Called "Newly Industrializing Economies (NIEs)". In: Kulessa M. (eds) The Newly Industrializing Economies of Asia. EuropeAsia-Pacific Studies in Economy and Technology. Springer, Berlin, Heidelberg. https://doi.org/10.1007/978-3-642-75705-1_13. 
Reliefweb. (2020). New water storage project to tackle drought - Thailand. ReliefWeb.

[Online]. Available: https://reliefweb.int/report/thailand/new-water-storage-project-tackledrought

Royal Irrigation Department. (2020). Emergency Continuous Management Plan. Royal Irrigation Department. [Online]. Available: https://www.hydro1.net/Data/update_web/Knowledgebase/10-01/July-7-85-63.pdf

Suebpongsang, P., Ekasingh, B., \& Cramb, R. (2020). Commercialisation of rice farming in northeast thailand. In White Gold: The Commercialisation of Rice Farming in the Lower Mekong Basin, pp. 39-68. Palgrave Macmillan, Singapore.

Thai Meteorological Department. (2021). The Climate of Thailand. [Online]. Available: http://climate.tmd.go.th/site/index

Udomkerdmongkol Manop \& Chalermpao Nawarat. (2020). Thai Agricultural Sector: From Problems to Solutions in Thailand. United Nations. [Online]. Available: https://thailand.un.org/en/103307-thai-agricultural-sector-problems-solutions

Wichai-utcha, N., \& Chavalparit, O. (2019). 3Rs Policy and plastic waste management in Thailand. Journal of Material Cycles and Waste Management, Vol. 21 No. 1, pp. 10-22. 